\title{
Strategi Pengembangan Objek Wisata Alam Air Terjun Tretes Wonosalam
}

\author{
Purbowo', Canggih Nailil Maghfiroh ${ }^{2 *}$, Dyah Ayu Sri Hartanti ${ }^{3}$ \\ 'Prodi Agribisnis, Universitas KH A Wahab Hasbullah \\ 2,3Prodi Rekayasa Pertanian dan Biosistem, Universitas KH A Wahab Hasbullah \\ "Corresponding author: canggihnailil@unwaha.ac.id
}

\begin{abstract}
Abstrak:Tujuan penelitian ini untuk menganalisis strategi prioritas dalam mengembangkan Objek Wisata Alam (OWA) air terjun Tretes Wonosalam. Metode analisis data menggunakanAnalitical Hierarchy Process (AHP) dengan melibatkan stakeholder Pemerintah desa Gelengdowo, UPT Tahura, warga desa Gelengdowo dan wisatawan sebagai responden penelitian. Hasil penelitian menunjukkan bahwa urutan prioritas dalam pengembangan OWA air terjun Tretes Wonosalam yaitu; Memperbaiki akses jalan menuju wisata; meningkatkan kemampuan bahasa asing bagi pemandu wisata; Promosi wisata yang melalui digital marketing; Mengembangkan potensi pertanian salak dan durian sebagai produk unggulan; Menjaga kebersihan dan kelestarian alam berdasarkan programCleanliness, Health, Safety and Environmental Sustainability (CHSE). Sehingga kerjasama antara pemerintah Desa Gelengdowo, Perhutani dengan UPT Tahura dalam program perbaikan jalan akses menuju tempat wisata menjadi prioritas utama dalam menyusun rencana pembangunan desa jangka menengah (RPJM-Desa) agar wisatawan merasa aman dan nyaman dalam berwisata.
\end{abstract}

Kata Kunci: Air terjun tretes, Durian, Salak, Wonosalam, AHP

\begin{abstract}
The purpose of the study was to analyze the priority strategies in developing the Natural Tourism Object (NTO) of the Tretes Wonosalam waterfall.The data analysis method has used the Analytical Hierarchy Process (AHP) and has involved respondents from stakeholders from the Gelengdowo village government, UPT Tahura, Gelengdowo village residents and tourists. The results of the study indicate that the order of priority in the OWA development strategy for the Tretes Wonosalam waterfall is: Improving road access to tourism; improving foreign language skills for tour guides; tourism promotion through digital marketing; Developing the potential of snakefruit and durian as superior products; Maintain cleanliness and sustainability of natural resources based on Cleanliness, Health, Safety and Environmental Sustainability (CHSE).Thus, the collaboration between the Gelengdowo Village government, State-Owned Forestry Company and UPT Tahura in the program to improve access roads to tourist attractions, is a top priority in preparing the medium-term village development plan (RPJM-Desa), so that tourists feel safe and comfortable when traveling.
\end{abstract}

Keywords: Tretes Waterfall, Durian, Snakefruit, Wonosalam

\section{PENDAHULUAN}

Kebijakan penguatan dan perluasan eksistensi promosi pariwisata Indonesia telah mencapai 15,54\% ke angka 12,2 juta kunjungan pada tahun 2016 (Kemenpar, 2017). Hal ini sejalan dengan arah kebijakan pengambangan pariwisata berdasarkan Peraturan Pemerintah nomor 50 (2011)dapat dilakukan melalui penguatan dan perluasan eksistensi promosi pariwisata Indonesia di dalam negeri maupun luar negeri. Disisi lain BAPPENAS menargetkan kontribusi pariwisata terhadap PDB sebesar 8\% dengan devisa sebesar 240 triliun rupiah dan 20 juta 
kunjungan wisatawan mancanegara pada tahun 2019. Namun ternyata pada realisasinya kontribusi pariwisata terhadap PDB sebesar 15\%, target devisa 280 triliun rupiah dengan membuka kesempatan kerja sebanyak 13 juta pekerja pada tahun 2019 (Ratman, 2016).

Pengembangan sektor wisata diwonosalam dilakukan dengan valuasi tentang persepsi, partisipasi dan keinginan masyarakat terhadap pengembangan destinasi wisata sekitar dan diperlukan strategi pemasaran pariwisata yang sesuai dengan kondisi destinasi wisatanya (Novaria, 2017). Salah satu destinasi unggulan di Wonosalam yaitu Objek wisata alam (OWA) air terjun tretes memiliki ketinggian 170 meter dengan panorama yang menakjubkan.Lokasi OWA air terjun tretes berada pada kawasan Taman Hutan Raya (TAHURA) Raden Soerjo yang termasuk dalam wilayah admistrasi pemerintahan kabupaten Jombangyang memiliki Keanekaragaman hayati terdiri dari flora dan fauna yang tersebar di berbagai titik lokasi hutan. Fatma, et al. (2017) menyatakan bahwa terdapat sebanyak delapan spesies dari familia Physciaceae (jamur) dan empat spesies dari familia Lobariaceae.

Valuasi ekonomi OWA air terjun Tretes Wonosalam mencapai Rp. 328.767 .120 pertahun dengan nilai WTP individu Rp 50,000 dan surplus konsumen Rp 27,397.26(Purbowo \& Daroini, 2021).Besarnya nilai valuasi tersebut mencerminkan potensi desa sebagai desa wisata yang berpeluang untuk dilakukan pengembangan dengan beberapa strategi alternatif pengembangan OWA agar kelestarian dan keberlajutan wisata. Tujuan penelitian ini untuk menganalisis strategi prioritas utama dalam mengembangkan Objek Wisata Alam (OWA) air terjun Tretes Wonosalam.

\section{METODE PENELITIAN}

Penelitian dilaksanakan di OWA air terjun Tretes Wonosalam kabupaten Jombang menggunakan data primer yang dikumpulkan menggunakan metode purposive sampling. Responden yang terlibat yaitu pengelola wisata dari UPT Tahura, Pemerintah Desa Gelengdowo, warga desa Gelengdowo serta wisatawan. Data dianalisis menggunakanAnalytical Hierarchy Process (AHP). Berikut matrik AHP berdasarkan tujuan, pelaku, faktor dan alternatif yang ditawarkan beserta langkah-langkah menyusun matrik:

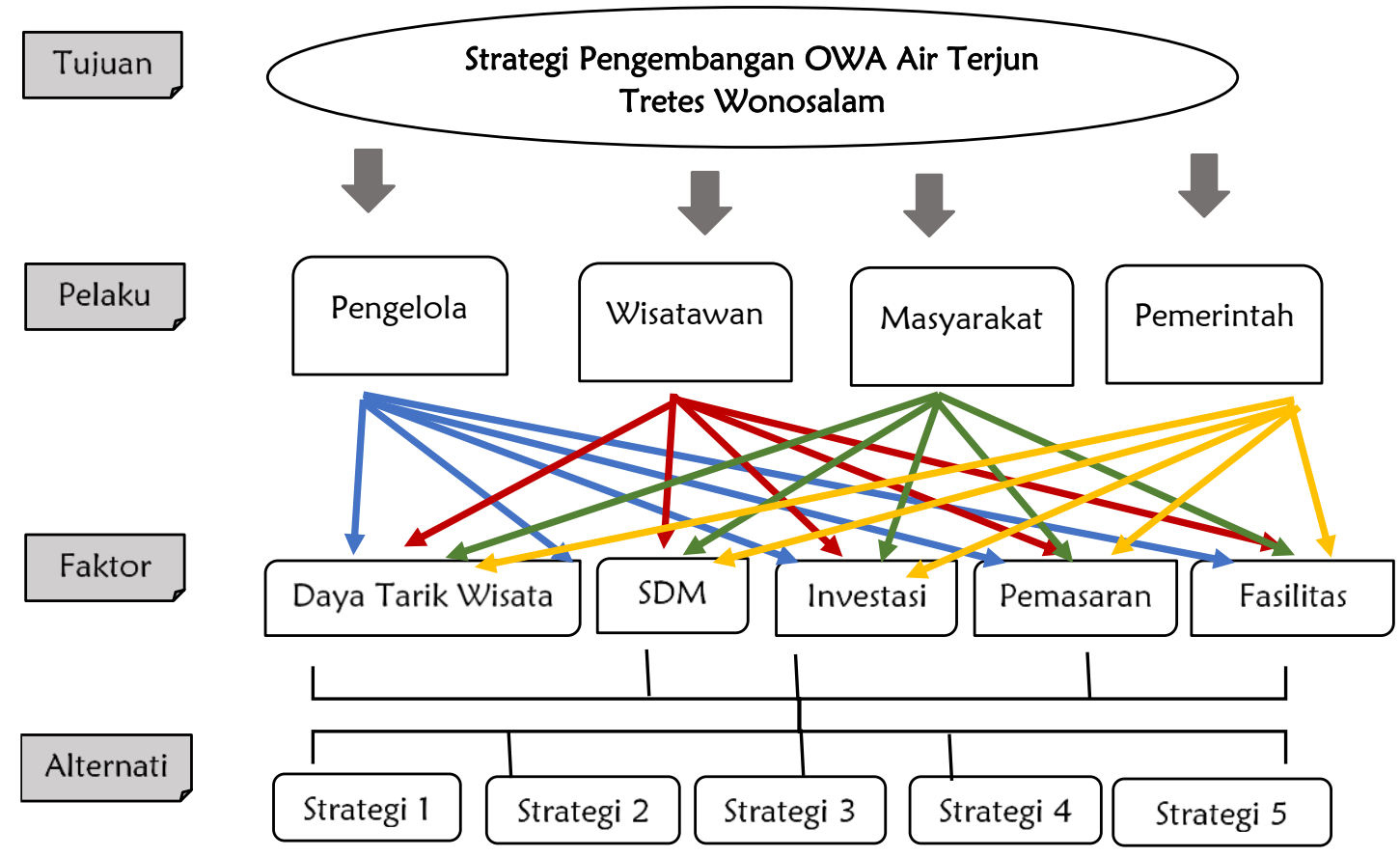

Bagan 1, Tujuan, pelaku, faktor dan alternative strategi 
A. Menentukan level prioritas antar kedua alternative yang ditawarkan dengan angka intensitas preferensi 1 hingga 9.

Tabel 1. Tabel Level Intensitas Preferensi

\begin{tabular}{cll}
\hline $\begin{array}{c}\text { Intensitas } \\
\text { Preferensi }\end{array}$ & \multicolumn{1}{c}{ Level } & \multicolumn{1}{c}{ Definisi } \\
\hline 1 & Equal Importance & Kedua alternatif strategi sama penting \\
3 & Moderate importance & Alternatif strategi sedikit lebih penting \\
5 & Strong importance & Alternatif strategi jelas lebih penting \\
7 & Very strong importance & Alternatif strategi sangat lebih penting \\
9 & Extreme importance & Alternatif strategi mutlak lebih penting \\
$2,4,6,8$ & - & Ragu diantara yang berdekatan \\
\hline
\end{tabular}

B. Membuat matrik strategi alternatif yang terdiri dari baris (vertikal) dan kolom (Horisontal) serta mengisi Kolom-kolom tersebut dengan intensitas preferensi (IP) antara 1 hingga 9.

C. Kolom yang berada di atas dengan yang di bawah diagonal (1/1) diisi saling berkebalikan (invers).

D. Menjumlah secara vertical pada masing-masing kolom strategi hingga terbentuk nilai total Z, Y, X, W dan V

E. Melakukan normalisasi angka secara vertical untuk dibagi dengan totalnya dengan catatan hasilnya minimum 0 maksimum 1 dan nilai totalnya harus sama dengan 1.

F. Menjumlah secara horizontal pada masing-masing baris strategi hingga terbentuk nilai $\mathrm{P}, \mathrm{Q}, \mathrm{R}, \mathrm{S}$ dan $\mathrm{T}$.

G. Menentukan nilai Priority Vector (PV) dengan membagi total vertical terhadap total keseluruhan (5). Hal ini bertujuan untuk mengetahui tingkat prioritas dari kelima strategi dimulai dari yang memiliki angka terbesar hingga terendah.

$\mathrm{H}$. Melakukan uji konsistensi yang bertujuan untuk mengetahui secara tepat pengisian kuisioner, apakah diisi secara tepat ataupun secara random (asal mengisi). Operasi uji konsistensi dilakukan dengan formulasi sebagai berikut:

$$
\begin{aligned}
& \lambda=\left[\frac{\overline{\text { Hasll }}}{P V}\right] \\
& \mathrm{Cl}=\frac{\lambda-\mathrm{n}}{n-1} \\
& \mathrm{RI}=\frac{1.98(\mathrm{n}-2)}{n} \\
& \mathrm{CR}=\frac{C I}{R I}
\end{aligned}
$$

Keterangan :

$\mathrm{CR}:$ Consistency Ratio

$\mathrm{Cl}$ : Consistency Index

$\mathrm{RI}$ : Random Index

$\mathrm{n}$ : jumlah data/strategi

Parameter:
$C R<0,01$
Konsisten
$C R=0$
Sangat Konsisten
$C R>0,01$
Tidak Konsisten 


\section{HASIL DAN PEMBAHASAN}

Susunan Hierarki terdiri atas tujuan, pelaku, dan faktor-faktor. Tujuan penyusunan hieararki untuk menentukan stratregi pengembangan OWA air terjun Tretes Wonosalalam dengan pelaku yang terlibat yaitu wisatawan, pengelola, pemerintah dan masyarakat sekitar. Faktor-faktor yang diidentifikasi yaitu dayatarik wisata, Sumber daya manusia, investasi, pemasaran dan fasilitas yang tersedia. Strategi alternatif yang terbentuk berdasarkan pasangan pelaku dan faktor-faktor yang menunjang pengembangan wisata yaitu sebagai berikut:

a. Strategi alternatif 1 (S1): Promosi wisata yang melalui digital marketing

b. Strategi alternatif2 (S2): Mengembangkan potensi pertanian salak dan durian

c. Strategi alternatif3 (S3): Memperbaiki akses jalan menuju wisata

d. Strategi alternatif4 (S4): Meningkatkan kemampuan bahasa asing bagi pengelola wisata

e. Strategi alternatif5 (S5): Menjaga kebersihan dan kelestarian sumberdaya alam sekitar Berikut hasil perhitungan susunan strategi yang ditawarkan dari faktor-faktor identifikasi

Tabel 2. Tabel Matrik Faktor Identifikasi

\begin{tabular}{cccccc} 
& $S 1$ & $S 2$ & $S 3$ & $S 4$ & $S 5$ \\
\hline$S 1$ & $1^{[\mathrm{A} 1]}$ & $1^{[\mathrm{B} 1]}$ & $1 / 3=0,33^{[\mathrm{C} 1]}$ & $1^{[\mathrm{D} 1]}$ & $3^{[\mathrm{E} 1]}$ \\
\hline$S 2$ & $1^{[\mathrm{AA} 2]}$ & $1^{[\mathrm{B} 2]}$ & $1 / 3=0,33^{[\mathrm{C} 2]}$ & $1^{[\mathrm{D} 2]}$ & $3^{[\mathrm{E} 2]}$ \\
\hline$S 3$ & $3^{[\mathrm{A} 3]}$ & $3^{[\mathrm{B} 3]}$ & $1^{[\mathrm{C} 13}$ & $3^{[\mathrm{D} 3]}$ & $9^{[\mathrm{E} 3]}$ \\
\hline$S 4$ & $1^{[\mathrm{A} 4]}$ & $1^{[\mathrm{B} 4]}$ & $1 / 3=0,33^{[\mathrm{C} 4]}$ & $1^{[\mathrm{D} 4]}$ & $7^{[\mathrm{E} 4]}$ \\
\hline$S 5$ & $1 / 3=0,33^{[\mathrm{A} 5]}$ & $1 / 3=0,33^{[\mathrm{B} 5]}$ & $1 / 9=0,11^{[\mathrm{C} 5]}$ & $1 / 7=0,144^{[\mathrm{D} 5]}$ & $1^{[\mathrm{E} 5]}$ \\
\hline Total & 6,33 & 6,33 & 2,11 & 6,14 & 23
\end{tabular}

Berdasarkan perbandingan antara strategi 1 (S1) terhadap strategi 2 (S2), responden menyatakan strategi 1 (S1) sama pentingnya dengan strategi 2 sehingga pada sel A2 diisi nilai 1 sedangkan sel B1 sebagai oposisi dinyatakan dengan $1 / 1=1$. Berdasarkan perbandingan antara strategi 1 (S1) terhadap strategi 3 (S3), responden lebih memilih strategi 1 (S1) dengan nilai rataan mendekati 3 sehingga pada sel A3 diisi nilai 3 sedangkan sel $\mathrm{C} 1$ sebagai oposisi dinyatakan dengan $1 / 3=0,33$. Berdasarkan perbandingan antara strategi 1 (S1) terhadap strategi 4 (S4), responden menyatakan bahwa strategi 1 (S1) sama pentingnya dengan strategi 4 (S4) dengan nilai rataan sama dengan 1 sehingga pada sel D1 diisi nilai 1 sedangkan sel A4 sebagai oposisi dinyatakan dengan $1 / 1=1$.Berdasarkan perbandingan antara strategi 1 (S1) terhadap strategi 5 (S5), responden lebih memilih strategi 5 (S5) dengan nilai rataan mendekati 3 sehingga pada sel E1 diisi nilai 3 sedangkan sel A5 sebagai oposisi dinyatakan dengan $1 / 3=0,33$.

Berdasarkan perbandingan antara strategi 2 (\$2) terhadap strategi 3 (\$3), responden lebih memilih strategi 2 (S2) dengan nilai rataan mendekati 3 sehingga pada sel B3 diisi nilai 3 sedangkan sel C2 sebagai oposisi dinyatakan dengan $1 / 3=0,33$.Berdasarkan perbandingan antara strategi 2 (\$2) terhadap strategi 4 (\$4), responden menyatakan bahwa strategi 4 (S4) sama pentingnya dengan strategi 2 (S2) dengan nilai rataan sama dengan 1 sehingga pada sel B4 diisi nilai 1 sedangkan sel D2 sebagai oposisi dinyatakan dengan $1 / 1=1$.Berdasarkan perbandingan antara strategi 2 (S2) terhadap strategi 5 (S5), responden lebih memilih strategi 5 (S5) dengan nilai rataan mendekati 3 sehingga pada sel E2 diisi nilai 3 sedangkan sel B5 sebagai oposisi dinyatakan dengan $1 / 3=0,33$.

Berdasarkan perbandingan antara strategi 3 (\$3) terhadap sstrategi 4 (\$4), responden lebih memilih strategi 4 (\$4) dengan nilai rataan mendekati 3 sehingga pada sel D3 diisi nilai 3 sedangkan sel C4 sebagai oposisi dinyatakan dengan $1 / 3=0,33$. Berdasarkan perbandingan 
antara strategi 3 (S3) terhadap strategi 5 (S5), responden lebih memilih strategi 5 (S5) dengan nilai rataan mendekati 9 sehingga pada sel E3 diisi nilai 9 sedangkan sel C5 sebagai oposisi dinyatakan dengan $1 / 9=0,11$. Berdasarkan perbandingan antara strategi 4 (S4) dengan strategi 5 (S5), responden lebih memilih strategi 5 (S5) dengan nilai rataan mendekati 7 sehingga pada sel E4 diisi nilai 7 sedangkan sel D5 sebagai oposisi dinyatakan dengan $1 / 7=0,14$.

Total perhitungan nilai pada kolom A secara vertikal yaitu diformulasikan dengan rumus penjumlahan (sum) $\mathrm{A} 1+\mathrm{A} 2+\mathrm{A} 3+\mathrm{A} 4+\mathrm{A} 5$.

Maka:A1+A2+A3+A4+A5 =1,00+1,00+3,00+1,00+0,33=6,33

Total perhitungan nilai pada kolom Bsecara vertikalyaitu diformulasikan dengan rumus penjumlahan (sum) B1+B2+B3+B4+B5.

Maka: $B 1+B 2+B 3+B 4+B 5=1,00+1,00+3,00+1,00+0,33=6,33$

Total perhitungan nilai pada kolom $C$ yaitu diformulasikan dengan rumus penjumlahan (sum) $\mathrm{C} 1+\mathrm{C} 2+\mathrm{C} 3+\mathrm{C} 4+\mathrm{C} 5$.

Maka: $\mathrm{C} 1+\mathrm{C} 2+\mathrm{C} 3+\mathrm{C} 4+\mathrm{C} 5=0,33+0,33+1,00+0,33+0,11=2,11$

Total perhitungan nilai pada kolom $\mathrm{D}$ yaitu diformulasikan dengan rumus penjumlahan (sum) $\mathrm{D} 1+\mathrm{D} 2+\mathrm{D} 3+\mathrm{D} 4+\mathrm{D} 5$.

Maka:D1+D2+D3+D4+D5 = 1,00 + 1,00 + 3,00 + 1,00 + 0,14 =6,14

Total perhitungan nilai pada kolom $\mathrm{E}$ yaitu diformulasikan dengan rumus penjumlahan (sum) $\mathrm{E} 1+\mathrm{E} 2+\mathrm{E} 3+\mathrm{E} 4+\mathrm{E} 5$.

Maka:E1+E2+E3+E4+E5 $=3,00+3,00+9,00+7,00+1,00=23,00$

Tabel 2. Tabel Matrik Normalisasi

\begin{tabular}{lrrrrr}
\hline & S1 (A) & S2 (B) & S3 (C) & S4 (D) & S5 (D) \\
\hline S1 (1) & $\frac{1,00}{6,33}=0,16$ & $\frac{1,00}{6,33}=0,16$ & $\frac{0,33}{2,11}=0,16$ & $\frac{1,00}{6,14}=0,16$ & $\frac{3,00}{23,00}=0,13$ \\
\hline S2 (2) & $\frac{1,00}{6,33}=0,16$ & $\frac{1,00}{6,33}=0,16$ & $\frac{0.33}{2,11}=0,16$ & $\frac{1,00}{6,14}=0,16$ & $\frac{7,00}{23,00}=0,13$ \\
\hline S3 (3) & $\frac{3,00}{6,33}=0,47$ & $\frac{3.00}{6,33}=0,47$ & $\frac{1.00}{2,11}=0,47$ & $\frac{3.00}{6,14}=0,49$ & $\frac{9.00}{23,00}=0,39$ \\
\hline S4 (4) & $\frac{1,00}{6,33}=0,16$ & $\frac{1,00}{6,33}=0,16$ & $\frac{0.33}{2,11}=0,16$ & $\frac{1,00}{6,14}=0.16$ & $\frac{7,00}{23,00}=0.30$ \\
\hline S5 (5) & $\frac{0,33}{6,33}=0,05$ & $\frac{0.33}{6,33}=0,05$ & $\frac{0.05}{2,11} 0,01$ & $\frac{0.14}{6,14}=0.02$ & $\frac{1.00}{23,00}=0.04$ \\
\hline Total & 1.00 & 1.00 & 1.00 & 1.00 & 1.00
\end{tabular}

Seluruh total masing-masing pada kolom A, B, C, D dan E dijumlahkan secara vertical sehingga memperoleh nilai total 1 .

Tabel 2. Tabel Penjumlahan Vertikal

\begin{tabular}{|c|c|c|c|c|c|c|}
\hline & $S 1(A)$ & S2 (B) & S3 (C) & S4 (D) & S5 (E) & TOTAL \\
\hline S1 (1) & $\begin{array}{c}\frac{1,00}{6,33}=0,16 \\
\text { (A1) }\end{array}$ & $\begin{array}{c}\frac{1,00}{6,33}=0,16 \\
\text { (B1) }\end{array}$ & $\begin{array}{c}\frac{0,33}{2,11}=0,16 \\
\text { (C1) }\end{array}$ & $\begin{array}{c}\frac{1,00}{6,14}=0,16 \\
\text { (D1) }\end{array}$ & $\begin{array}{c}\frac{3,00}{23,00}=0,13 \\
\text { (E1) }\end{array}$ & 0,77 \\
\hline$S 2(2)$ & $\begin{array}{c}\frac{1,00}{6,33}=0,16 \\
\text { (A2) }\end{array}$ & $\begin{array}{c}\frac{1,00}{6,33}=0,16 \\
\text { (B2) }\end{array}$ & $\begin{array}{c}\frac{0.33}{2,11}=0,16 \\
\text { (C2) }\end{array}$ & $\begin{array}{c}\frac{1,00}{6,14}=0,16 \\
\text { (D2) }\end{array}$ & $\begin{array}{c}\frac{7,00}{23,00}=0,13 \\
\text { (E2) }\end{array}$ & 0,77 \\
\hline S3 (3) & $\begin{array}{c}\frac{3,00}{6,33}=0,47 \\
\text { (A3) }\end{array}$ & $\begin{array}{c}\frac{3.00}{6,33}=0,47 \\
\text { (В3) }\end{array}$ & $\begin{array}{c}\frac{1.00}{2,11}=0,47 \\
\text { (C3) }\end{array}$ & $\begin{array}{c}\frac{3.00}{6,14}=0,49 \\
\text { (D3) }\end{array}$ & $\begin{array}{c}\frac{9.00}{23,00}=0,39 \\
(E 3)\end{array}$ & 2,30 \\
\hline $54(4)$ & $\begin{array}{c}\frac{1,00}{6,33}=0,16 \\
\text { (A4) }\end{array}$ & $\begin{array}{c}\frac{1,00}{6,33}=0,16 \\
\text { (B4) }\end{array}$ & $\begin{array}{c}\frac{0.33}{2,11}=0,16 \\
\text { (C4) }\end{array}$ & $\begin{array}{c}\frac{1,00}{6,14}=0.16 \\
\text { (D4) }\end{array}$ & $\begin{array}{c}\frac{7,00}{23,00}=0.30 \\
\text { (E4) }\end{array}$ & 0,94 \\
\hline
\end{tabular}




\begin{tabular}{ccccccc}
\hline S5 (5) & $\frac{0,33}{6,33}=0,05$ & $\frac{0.33}{6,33}=0,05$ & $\frac{0.05}{2,11} 0,01$ & $\frac{0.14}{6,14}=0.02$ & $\frac{1.00}{23,00}=0.04$ & 0,22 \\
& (A5) & (B5) & (C5) & (D5) & (E5) & \\
\hline Total & 1.00 & 1.00 & 1.00 & 1.00 & 1.00 & 5
\end{tabular}

Seluruh total masing-masing pada baris 1, 2, 3, 4 dan 5 dijumlahkan secara horisontal sehingga memperoleh nilai sebagai berikut :

1. $\mathrm{A} 1+\mathrm{B} 1+\mathrm{C} 1+\mathrm{D} 1+\mathrm{E} 1=$ Total $\mathrm{S} 1(1)$

$0,16+0,16+0,16+0,16+0,13=0,77$

2. $\mathrm{A} 2+\mathrm{B} 2+\mathrm{C} 2+\mathrm{D} 2+\mathrm{E} 2=$ Total $\mathrm{S} 2(2)$

$0,16+0,16+0,16+0,16+0,13=0,77$

3. $\mathrm{A} 3+\mathrm{B} 3+\mathrm{C} 3+\mathrm{D} 3+\mathrm{E} 3=$ Total $\mathrm{S3}(3)$

$0,47+0,47+0,47+0,49+0,39=2,30$

4. $\mathrm{A} 4+\mathrm{B} 4+\mathrm{C} 4+\mathrm{D} 4+\mathrm{E} 4=$ Total $\mathrm{S} 4$ (4)

$0,16+0,16+0,16+0,16+0,30=0,94$

5. $\mathrm{A} 5+\mathrm{B} 5+\mathrm{C} 5+\mathrm{D} 5+\mathrm{E} 5=$ Total $\mathrm{S} 5(5)$

$0,05+0,05+0,01+0,02+0,04=0,22$

Menentukan PV (Priority Vector) yaitu nilai faktor prioritas yang ditentukan dari pembagian total secara horizontal $(\mathrm{H})$ dengan nilai total $\mathrm{H}$ atau total $\mathrm{V}$ yaitu 5 . Semakin besar PV maka akan menjadi strategi prioritas yang utama kemudian nilai tertinggi kedua dan seterusnya menjadi prioritas kedua hingga terakhir kelima. Hasil analisis diatas menunjukkan bahwa nilai PV tertinggi terdapat pada strategi 3 (S3) yaitu sebesar 0,46 kemudian prioritas kedua diikuti strategi 4 (S4) sebesar 0,19 prioritas ketiga ditempati oleh strategi 1 (S1) dan strategi 2 (\$2) yang kedua nilainya seri yaitu sebesar 0,15. Lalu strategi diranking terakhir ditempati oleh strategi 5 (S5) dengan nilai 0,04.

Dari hasil tersebut masih perlu dilakukan uji konsistensi yang bertujuan untuk melihat apakah jawaban yang diberikan responden telah nyata konsisten atau tidak. Untuk menentukan hal tersebut maka diperlukan formulasi sebagai berikut:

1. Menentukan hasil kali (HK) yang merupakan perkalian nilai ke lima strategi terhadap PV. Perkalian dilakukan secara vertikal dan horizontal sesuai dengan banyaknya strategi.

Hasil Kali $(\mathrm{HK})=($ S1 $\times$ PV1 $)+($ S2 $\times$ PV2 $)+($ S3+PV3 $)+($ S4 $\times$ PV4 $)+($ S5 $\times$ PV5 $)$

Maka :

HK Baris $1=(1 \times 0,15)+(1 \times 0,15)+(0,33 \times 0,46)+(1 \times 0,19)+(3 \times 0,04)$

HK Baris $1=0,78$

HK Baris $2=(1 \times 0,15)+(1 \times 0,15)+(0,33 \times 0,46)+(1 \times 0,19)+(3 \times 0,04)$

HK Baris $2=0,78$

HK Baris $3=(3 \times 0,15)+(3 \times 0,15)+(1 \times 0,46)+(3 \times 0,19)+(9 \times 0,04)$

HK Baris $3=2,35$

HK Baris $4=(1 \times 0,15)+(1 \times 0,15)+(0,33 \times 0,46)+(1 \times 0,19)+(7 \times 0,04)$

HK Baris $4=0,96$

HK Baris $5=(0,33 \times 0,15)+(0,33 \times 0,15)+(0,11 \times 0,46)+(0,14 \times 0,19)+(1 \times 0,04)$

HK Baris $5=0,23$

2. Menentukan nilai lamda $(\lambda)$ dengan formulasi $\lambda=\left[\left(\right.\right.$ Hasil Kali $\left.^{-} / \mathrm{PV}\right]$

$\lambda=\left[\left(\right.\right.$ Hasil Kali $\left.^{-} / \mathrm{PV}\right]$

$\lambda 1=\left[\left(\mathrm{HK}^{2}\right) /(\mathrm{PV} 1)\right]=[0,78 / 0,15]=5,11$

$\lambda 2=[(\mathrm{HK} 2)-(\mathrm{PV} 2)]=[0,78 / 0,15]=5,11$

$\lambda 3=[(\mathrm{HK} \mathrm{3}) /(\mathrm{PV} 3)]=[2,35 / 0,46]=5,11$

$\lambda 4=\left[\left(\mathrm{HK}^{4}\right)^{-} /(\mathrm{PV} 4)\right]=[0,96 / 0,19]=5,12$

$\lambda 5=[($ HK 5) $/($ PV 5) $]=[0,23 / 0,04]=5,01$

$\lambda=(5,11+5,11+5,11+5,11+5,12+5,01) / 5=5,09$ 
3. Menentukan nilai $\mathrm{Cl}$ dengan formulasi

$$
\begin{aligned}
& \mathrm{Cl}=(\lambda-n) /(n-1) \\
& \mathrm{Cl}=(\lambda-n) /(n-1) \quad() \\
& \mathrm{Cl}=(5,09-5) /(5-1)=0,09 / 4=0,022
\end{aligned}
$$

4. Menentukan nilai RI dengan formulasi $\mathrm{RI}=(1.98(\mathrm{n}-2)) / \mathrm{n}$

$$
\begin{aligned}
\mathrm{RI} & =(1.98(\mathrm{n}-2)) / \mathrm{n} \\
\mathrm{RI} & =(1.98(\mathrm{n}-2)) / \mathrm{n} \\
& =(1.98(5-2)) / 5=(1.98(3)) / 5=1,188
\end{aligned}
$$

5. Menentukan nilai $C R$ dengan formulasi $C R=C l / R I$

$$
\begin{aligned}
& C R=C l / R I \\
& C R=C l / R I=0,022 / 1,188=0,01
\end{aligned}
$$

Keterangan:

CR: Consistency Ratio

$\mathrm{Cl}$ : Consistency Index

\begin{tabular}{|c|c|c|c|c|c|c|c|}
\hline \multicolumn{2}{|c|}{ S1 (A) } & S2 (B) & S3 (C) & S4 (D) & S5 (E) & Total & PV \\
\hline S1 (1) & 0,16 (A1) & $0,16^{(B 1)}$ & 0,16 (C1) & $0,16^{(D 1)}$ & $0,13^{(E 1)}$ & 0,77 & $\frac{0,77}{5.00}=0,15$ \\
\hline S2 (2) & 0,16 (A2) & $0,16^{\text {(B2) }}$ & 0,16 (C2) & 0,16 (D2) & 0,13 (E2) & 0,77 & $\frac{0,77}{5.00}=0,15$ \\
\hline S3 (3) & $0,47^{(\mathrm{A} 3)}$ & 0,47 (В3) & 0,47 (c3) & $0,49^{(\mathrm{D} 3)}$ & 0,39 (E3) & 2,30 & $\frac{2,30}{5.00}=0.46$ \\
\hline S4 (4) & 0,16 (A4) & $0,16^{(B 4)}$ & 0,16 (C4) & $0,16 \quad$ (D4) & $0,30^{(E 4)}$ & 0,94 & $\frac{0,94}{5.00}=0,19$ \\
\hline S5 (5) & 0,05 (A5) & $0,05^{(B 5)}$ & 0,01 (C5) & 0,02 (D5) & 0,04 (E5) & 0,22 & $\frac{0,22}{5.00}=0.04$ \\
\hline $\begin{array}{l}\text { Total } \\
\text { (V) }\end{array}$ & 1.00 & 1.00 & 1.00 & 1.00 & 1.00 & 5.00 & \\
\hline
\end{tabular}

RI: Random Index

n: jumlah data/strategi

$C R<0,01 \quad$ Konsisten

$C R=0 \quad$ Sangat Konsisten

$C R>0,01 \quad$ Tidak Konsisten

Nilai $C R$ telah terbentuk yaitu sebesar 0,01. Artinya jawaban responden konsisten

Tabel 3. Nilai PV

Strategi 3 (S3) menduduki rangking satu dengan nilai PV tertinggi yaitu sebesar 0,46. Strategi 3 yang dimaksud yaitu memperbaiki akses jalan menuju lokasi wisata air terjun tretes. Untuk mencapai air terjun tersebut, pengunjung harus melewati jalan desa dan jalan perhutani yang berada di antara wilayah administrasi desa serta Taman Hutan Raya (TAHURA). Oleh karena itu diperlukan kerjasama antara pemerintah desa Gelengdowo serta Perhutani berupa perbaikan maupun pelebaran jalan dengan rabat beton atau aspal. Kondisi jalan saat ini masih rusak sehingga pengunjung sangat was-was dalam berkendara.

Menurut Susilo \& Hartantyo, (2017) kerusakan jalan beton disebabkan oleh tidak terdapatnya tulangan pada plat serta keretakan memanjang yang paling dominan dan berkurangnya mutu beton akibat kurangnya pengawasan. Mulyati \& Herman(2015) juga menambahkan bahwa campuran adukan beton 1:2:3 yang terdiri dari semen:pasir:kerikil dapat menahan beban dengan kuat tekan beton antara $131,97 \mathrm{~kg} / \mathrm{cm} 2-238,2 \mathrm{~kg} / \mathrm{cm} 2$. Sehingga harapan kedepan pembangunan jalan menuju wisata diharapkan sesuai atau mendekati campuran beton yang telah direkomendasikan agar anggaran pembangunan tidak. 
Oleh karena itu sinergitas antara pemerintah desa sangat diperlukan mengingat kewenangannya yang luas dalam pengelolaan dana desa untuk pembangunan infrastruktur jalan menuju tempat wisata. Menurut (Jamaluddin et al., 2018) kewenangan yang luas pada pengelolaan dana desa tidak memberi dampak signifikan terhadap pertumbuhan pembangunan daerah. Disisi lain desa juga mendapat dana yang di namakan alokasi dana desa (ADD). Pengelolaan ADD hendaknya berlandaskan seni manajemen yaitu perencanaan, pelaksanaan, penatausahaan, pelaporan, dan pertanggungjawaban dengan 63 indikator (Tikollah \& A. Ngampo, 2018).

Keterlibatan badan usaha milik desa (BUMDES) memiliki peran dalam peningkatan pendapatan asli desa (PADes) dan sebagai sarana peningkatan perekonomian desa (Dewi, 2014). BUMDes serahusnya berlandaskan konsep kawasan komoditas unggulan yang berdampak pada aspek sosial dan ekonomi masyarakat desa serta agar BUMDes dapat berkembang dan menjadi lembaga perekonomian desa yang berdaya saing (Harmiati \& Zulhakim, 2017)

Keterlibatan perhutani dalam pembangunan akses jalan juga sangat diperlukan mengingat bahwa akses menuju air terjun tretes Wonosalam melewati kawasan perhutani. Sehingga diperlukan kerjasama atau sinergitas antara pemerintah desa, masyarakat desa, UPT Tahura R. Soerjo terhadap Perhutani. MenurutPrastyo \& Hidayat(2016) kemitraan antara masyarakat desa dengan perhutani dapat dilakukan dengan kesepatan yang adil dan terbuka. Hal ini terbukti dengan peningkatan penghasilan masyarakat pada kegiatan penggarapan lahan sebesar Rp.442.450 lebih besar dari pada penghasilan penyadap getah pinus sebesar Rp.245.500. Wilujeng (2015) juga menambahkan bahwa pentingnya sosialisasi tentang pemahaman pengelolaan hutan bersama kepada masyarakat agar implementasi kebijakan Pengelolaan Hutan Bersama Masyarakat (PHBM) dapat dijalankan dengan optimal agar dapat mengangkat perekonomian masyarakat.

Posisi kedua ditempati oleh strategi 4 (S4) dengan nilai PV sebesar 0,19. Strategi 4 yang dimaksud yaitu meningkatkan kemampuan bahasa asing bagi pengelola wisata. Hal ini bertujuan untuk mengantisipasi adanya kunjungan dari wisatawan mancanegara agar pemandu atau tour guide dapat dengan leluasa memberikan penjelasan tentang kondisi wisata alam air terjun tretes Wonosalam. Hal ini sangat penting karena Bahasa asing memiliki peran dalam penyampaian informasi kepada pengunjung, salah satunya yaitu Bahasa inggris.

Prachanant, (2012) menyatakan bahwa tiga fungsi utama kemampuan bahasa Inggris yaitu sebagai sarana pemberi informasi, pelayanan dan menawarkan bantuan. Selain itu pengelola wisata juga memerlukan konsep humor dengan mengangkat isu-isu praktis dalam penerapannya agar pengunjung tidak bosan (Pabel \& Pearce, 2018). Pelayanan pemandu wisata (tour guide services) memiliki pengaruh yang signifikan terhadap kepuasan pengunjung serta intensitas kunjungan kembali (re-visiting)(Oter \& Çetinkaya, 2016).

Menurut peraturan menteri wisata Republik Indonesia nomor 12 tahun 2016 (Permenpar RI, 2016) pengelolaan destinasi pariwisata berkelanjutan yang efektif mencakup keterlibatan masyarakat lokal yang disebut kelompok sadar wisata. Pembinaan kelompok sadar wisata (POKDARWIS) sangat penting dilakukan karena perannya sebagai event organizer (EO) wisata di desa Gelengdowo serta sebagai penyampai aspirasi dari masyarakat lokal. Sedangkan Putri \& Adinia (2018) menambahkan bahwa partisipasi masyarakat dalam mengembangkan objek wisata lokal di desanya dapat meningkatkan kesejahteraan akan berdampak pada perubahan sosial masyarakat sekitar.

Namun keterlibatan perempuan di desa Gelengdowo justru sangat kurang dominan dalam mengambil peran dalam pengembangan wisata. Padahal menurut Purbowo \&Widodo(2018) menyatakan bahwa perempuan memiliki keterlibatan peran dalam aktivitas produktif maupun reproduktif dalam sektor pertanian. Hal tersebut seharusnya menjadi acuan dalam melibatkan perempuan pedesaan untuk meningkatkan kesejahteraan rumah tangganya melalui pariwisata lokal. Pettersson \& Cassel, (2014) juga menambahkan para wanita pedesaan dapat membangun dan mengembangkan kewirausahaan dengan produk Agribisnis berdasarkan citra rumah tangga pedesaan sebagai representasi diri mereka sebagai wanita petani tradisional. 
Strategi 1 (S1) dan strategi 2 (S2) menempati posisi yang sama yaitu pada rangking ketiga dengan total nilai PV sebesar 0,15. Strategi 1 (S1) yaitu Promosi wisata melalui digital marketing. Platform media sosial yang banyak digemari masyarakat generasi milenial dan $Z$ yaitu Instagram dan tiktok. Melalui kedua media tersebut dapat dibuat video keindahan OWA air terjun tretes Wonosalam. Dengan mengikuti sound trending pada media tik tok dan reels Instagram, video akan muncul di FYP dan dilihat oleh banyak pemirsa dengan sebutan "Viral". Video promosi dapat diambil dari sisi keindahan alam maupun budaya "Ken-Duren" yang bermaknasebagai tindakan mengucap rasa syukur atas panen raya buah durian(Sulistiyono, 2015).

Promosi wisata menggunakan video lebih efektif dan efisien dibandingkan dengan blosur yang menghabiskan kertas yang justru menimbulkan penumpukan sampah. Menurut Harrigan et al., (2017) media sosial adalah saluran yang ideal untuk melaluinya menginspirasi penyerapan, identifikasi, dan interaksi pengunjung dengan suatu brand. Media sosial Tiktok sebagai sarana promosi berpengaruh terhadap minat beli produk (Mumtaz \& Saino, 2021). Begitupun menurut Fitri \& Dwiyanti, (2021) media sosial tiktok dan influencer memiliki peran dalam meningkatkan penjualan produk. Selain itu Yachin(2018) juga menambahkan upaya untuk meningkatkan kapasitas pelayanan wisata, pengelola juga harus memahami persepsi pengunjung terhadap pengalamannya dalam berwisata serta melibatkannya dalam berpromosi.

Strategi 2 (S2) yaitu mengembangkan agrowisata salak dan durian beserta produk olahannya. Terdapat kebun salak yang belum dimanfaatkan sebagai agrowisata, padahal letak yang berdampingan akan melengkapi wisatawan dalam menikmati keindahan sekitar. Chusnah et al., (2019) menambahkan bahwa agrowisata durian dapat dikembangkan dengan memanfaatkan potensi wisata disekitarnya. Sehingga kedepan harapannya wisatawan tidak hanya pulang dengan tangan hampa, namun mendapatkan pengalaman agrowisata petik salak. Sehingga dominasi komoditas unggulan buah salak dapat dijadikan mascot potensi desa gelengdowo sebagai branding destinasi desa wisata.

Destinasi wisata yang berlandaskan keramahan lokal dapat memperkuat identitas/merek pariwisata nasional, sedangkan destinasi yang mengarah pada sikap kurang ramah dapat melemahkannya (Santos \& Ciraldi, 2017).Menurut (Foroudi, 2019) identitas mencakup penyebaran dimensi sikap merek dengan dua komponen asosiasi merek dan kepercayaan merek terdiri dari keakraban merek, pengenalan merek dan konsistensi dalam reputasi merek serta diawali dengan penerapan kinerja merek. Selain identitas/maskot diperlukan pula slogan untuk menciptakan kesan kepada pengunjung wisata. Menurut Pan (2019) penciptaan slogan pariwisata yaitu pertama mengidentifikasi atribut yang sangat diinginkan seperti atribut valensi, gairah, serta tampilan. Kedua memilih kata-kata yang tepat berdasarkan kepribadian identitas/merk, dimensi budaya target pasar, dan motivasi perjalanan dan ketiga mengubah kata-kata ini menjadi slogan yang meyakinkan.

Strategi terakhir ditempati oleh strategi 5 (S5) yaitu menjaga kebersihan dan kelestarian sumberdaya alam sekitar. Pengunjung dalam berwisata memiliki berbagai tujuan diantaranya kencan, piknik, refresing atau sebagai sarana pendidikan. Diantara berbagai tujuan tersebut pengunjung biasanya membawa makanan ataupun minuman yang menyisakan permasalahan berupa sampah plastik. Hal ini merupakan permasalahan klasik yang sangat sulit untuk ditangani apabila pengunjung bersifat acuh terhadap kebersihan dan kelestarian lingkungan. Oleh sebab itu pengunjung seharusnya diwajibkan membawa kembali sampah yang dibawanya agar kondisi wisata air terjun tretes Wonosalam tetap bersih dan lestari sumberdaya alamnya.

Kelestarian sumberdaya alam wisata air terjun tretes Wonosalam patut untuk dilestarikan baik flora maupun fauna. Menurut Karim(2018) pelestarian lingkungan hidup dapat dilakukan dengan mengembangkan partisipasi melalui keterlibatan kelompok sebagai media komunikasi untuk merumuskan penyebab terjadinya kerusakan lingkungan hidup, serta menemukan pemecahan masalah melalui pendidikan agama. Sehingga penerapan CHSE perlu dilakukan untuk mencegah dan mengatasi keberlanjutkan desa wisata. Menurut Arlinda \& Sulistyowati (2021) penerapan program CHSE berpengaruh signifikan terhadap kepuasan pengunjung, pengembangan ekonomi pariwisata dan industri kreatif. 


\section{KESIMPULAN}

Prioritas utama dalam mengambangkan OWA air terjun tretes wonosalam adalah perbaikan akses jalan desa maupun jalan perhutani menuju lokasi wisata. Prioritas kedua Membekali kemampuan bahasa asing bagi pedagang dan pemandu wisata agar mampu berkomunikasi dengan baik.Prioritas selanjutnya melakukan promosi dengan menggandeng patner media sosial terkini seperti tiktok dan Instagram yang mampu menarik perhatian wisatawan generasi $Z$ dan milenial. Memberdayakan potensi agrowisata buah salak dan durian sebagai produk unggulan desa serta membuat diferensiasi produk olahan untuk meningkatkan nilai tambah.Prioritas terakhir yaitu menjaga kebersihan dan kelestarian alam berdasarkan program adaptasi Cleanliness, Health, Safety and Environmental Sustainability (CHSE). Harapan kedepan OWA Air terjun tretes Wonosalam dapat menarik banyak wisatawan local maupun mancanegara.

\section{UCAPAN TERIMA KASIH}

Terimakasih kepada UPT Tahura R Soerjo yang telah memberikan izin penelitian dan rekan yang telah membantu pengambilan data penelitian. Penelitian ini tidak didanai oleh sumber pendanaan eksternal.

\section{DAFTAR PUSTAKA}

Arlinda, F., \& Sulistyowati, R. (2021). Pengaruh Penerapan Program Adaptasi CHSE (Cleanliness, Health, Safety, Environment) terhadap Kepuasan Pengunjung Destinasi Wisata Kabupaten Kediri. Jurnal Pendidikan Tata Niaga (JPTN), 9(3), 1404-1416. https://ejournal.unesa.ac.id/index.php/jptn/article/view/40351

Chusnah, M., Sumardji, S., \& Daroini, A. (2019). Strategi Pengembangan Durian Wonosalam Agrowisata Jombang. JURNAL AGRI-TEK: Jurnal Penelitian IImu-llmu Eksakta, 20(2), 53-61. https://doi.org/10.33319/agtek.v20i2.59

Fatma, Y., Mahanal, S., \& Sari, M. S. (2017). Keanekaragaman Familia Physciaceae dan Lobariaceae di Taman Hutann Raya Raden Soerjo Sebagai Bahan Ajar Pada Matakuliah Mikrobiologi. Jurnal Pendidikan: Teori, Penelitian, Dan Pengembangan, 2, 179-185.

Fitri, A. I., \& Dwiyanti, S. A. I. (2021). Efektivitas Media Tiktok Dan Influencermendongkrak Penjualan Lippie Serum Raeccadipandemi Covid19. Jurnal Ekonomi Dan Bisnis (EK\&BI), 4(1), 345-353. https://doi.org/10.37600/ekbi.v4i1.210

Foroudi, P. (2019). Influence of brand signature, brand awareness, brand attitude, brand reputation on hotel industry's brand performance. International Journal of Hospitality Management, 76(01), 271-285.

Peraturan Pemerintah Republik Indonesia Rencana Induk Pembangunan Kepariwisataan Nasional Tahun 2010-2025, Pub. L. No. Number 50 Year 2011 (2011).

Harmiati, \& Zulhakim, A. A. (2017). Eksistensi Badan Usaha Milik Desa (BUMDes) dalam Mengembangkan Usaha dan Ekonomi Masyarakat Desa yang Berdaya Saing di Era Masyarakat Ekonomi ASEAN.

Harrigan, P., Evers, U., Miles, M., \& Daly, T. (2017). Customer engagement with tourism social media brands. Tourism Management, 59, 597-609.

Jamaluddin, Y., Sumaryana, A., Rusli, B., \& Buchari, R. A. (2018). Analisis Dampak Pengelolaan dan Penggunaan Dana Desa terhadap Pembangunan Daerah. Jurnal IImu Pemerintahan Dan Sosial Politik, 6(1), 14-24.

Karim, A. (2018). Mengembangkan Kesadaran Melestarikan Lingkungan Hidup Berbasis Humanisme Pendidikan Agama. Edukasia : Jurnal Penelitian Pendidikan Islam, 12(2), 309.

Kemenpar. (2017). Laporan Akuntabilitas Kinerja Kementrian Pariwisata Tahun 2016.

Mulyati, \& Herman. (2015). Komposisi dan Kuat Tekan Beton pada Campuran Portland Composite Cement, Pasir dan Kerikil Sungai. Jurnal Momentum, 17(2), 1-5.

Mumtaz, Z. S., \& Saino. (2021). Pengaruh penggunaan aplikasi tik tok sebagai media promosi dan trend glow up terhadap minat beli produk kecantikan The effect of using the Tik Tok application as a promotional medium and the glow up trend on interest in buying 
beauty products. Jurnal Manajemen, 13(2), 282-291.

Novaria, R. and A. R. (2017). Pengembangan Community Based Tourism sebagai Strategi Pemberdayaan Masyarakat dan Pemasaran Pariwisata di Wonosalam Kabupaten Jombang. In Prosiding Seminar dan call paper (pp. 91-101).

Oter, Z., \& Çetinkaya, M. Y. (2016). Role of tour guides on tourist satisfaction level in guided tours and impact on re-visiting Intention : a research in Istanbul. De Gyuter, 7(1), 40-54.

Pettersson, K., \& Cassel, S. H. (2014). Women tourism entrepreneurs : doing gender on farms in Sweden. Gender in Management: An International Journal Women, 29(8), 487-504.

Prachanant, N. (2012). Needs Analysis on English Language Use in Tourism Industry. Procedia - Social and Behavioral Sciences, 66, 117-125.

Prastyo, E., \& Hidayat, K. (2016). Pola Kemitraan Antara Perum Perhutani Dengan Masyarakat Desa Hutan (Studi Kasus Program PKPH di Desa Kucur Dau, Kabupaten Malang). Habitat, 27(3), 139-149. https://doi.org/10.21776/ub.habitat.2016.027.3.16

Purbowo, \& Daroini, A. (2021). Determining Tourist Visits and Economic Valuation of Natural Attraction of Tretes Waterfall of Wonosalam. Agriscience, 1(2014), 625-637.

Purbowo, \& Widodo, S. (2018). A Study on the Impact of Commodity Changes to the Role and Strategy of Women's Livelihood. Gender Issues, 35(4). https://doi.org/10.1007/s12147-018-9214-4

Putri, F. A., \& Adinia, N. C. (2018). The Role of Communication in Sustainable Development Tourism: A Case Study on Community-based Tourism (Pokdarwis) in Nglanggeran Village. Jurnal Komunikasi Indonesia, VII(2), 153-161.

Ratman, D. R. (2016). Pembangunan destinasi pariwisata prioritas 2016 - 2019. In Rapat Koordinasi Nasional Kementerian Pariwisata "Akselerasi Pembangunan Kepariwisataan Dalam Rangka Pencapaian Target 12 Juta Wisman dan 260 Juta Wisnus 2016." http://www.kemenpar.go.id/userfiles/Paparan - Deputi BPDIP.pdf

Santos, G. E. de O., \& Giraldi, J. de M. E. (2017). Reciprocal effect of tourist destinations on the strength of national tourism brands. Tourism Management, 61, 443-450.

Sulistiyono, I. (2015). Ken-Duren Wonosalam (Studi Deskriptif: Makna Ken-Duren Wonosalam pada Masyarakat Kecamatan Wonosalam, Kabupaten Jombang). AntroUnairdotNet, 4(1), 77-85.

Susilo, H., \& Hartantyo, S. D. (2017). Analisa Kerusakan Jalan Beton Pada Ruas. CIVILA, 2(1), $1-8$.

Tikollah, M. R., \& A. Ngampo, M. Y. (2018). Analisis Pengelolaan Alokasi Dana Desa (Add) Di Kecamatan Mare Kabupaten Bone. JEKPEND: Jurnal Ekonomi Dan Pendidikan, 1(1), 87. https://doi.org/10.26858/jekpend.vli1.5064

Yachin, J. M. (2018). The 'customer journey': Learning from customers in tourism experience encounters. Tourism Management Perspectives, 28, 201-210. 